\title{
The Problem of Financial Management and Improvement Measures in the Countryside
}

\author{
Hong-Jing ZHANG ${ }^{1, a,{ }^{*},}$, Jin-Bao ZONG ${ }^{2, b}$ \\ ${ }^{1}$ School of Economics and Management, Northeast Dian Li University, Jilin 132012, Jilin Province, \\ China \\ azhanghongjing001@sina.com, ${ }^{b} 553172436 @ q q . c o m$ \\ ${ }^{*}$ Corresponding author
}

Keywords: The accounting in the countryside financial information, The basic environment of the accounting.

\begin{abstract}
So far, The financial management in the countryside has many problems, These problems have hindered the development of economic, This article elaborates four modes of financial management system in the countryside and their advantages, their disadvantages, analyses the failure of four management modes profoundly, And then proposes many measures to solve problems, Try my best to improve the financial management in the countryside.
\end{abstract}

\section{Introduction}

With the announcement of "the first file of the central government" in 2013, The central government focuses on the "three problems of agriculture" again, will continue the deepen reform and accelerate the decision of modern development in the countryside. The reform of the countryside is all aspects of the reform, At this stage, To solve the financial problems is the first, The chaos of the financial management not only blocks the modern of the agriculture, but also causes the tensions between officials and the masses. Therefore, we need to find some improvement measures, To specify the financial management in the countryside.

Four Modes of Financial Management System in the Countryside and Their Advantages, Their Disadvantages.

\section{The Independent Financial Management Mode}

The accounting personnel is selected by themselves in this mode, They accept the guide and supervise of the government departments, and it should be responsible for the villagers.

This mode mobilizes the responsibility consciousness of the villagers, but this causes that the accounting personnel is not independent to the village committee, Even village cadres intervene the work of financial management, So the stability of the accounting personnel is very weak, These problems encourage the village cadres start to have a corruption.

\section{Accounting Accreditation System Mode}

In this mode, a suitable candidate will be appointed as a natural villagers of accounting by the government, The government will do many works to the accounting personnel who are appointed by the villagers, these works include the inspection、 supervision、 management v training and personnel work, this mode makes the accounting personnel independent from the village committee, the accounting personnel not only need to accept the government supervision, but also accept the supervision of the villagers, The dual supervision is a kind of strengthening accounting supervision of the rural financial management mode, Many scholars criticize this mode, firstly, they point out 
this mode lacks the basis of legal, they think it is a violation of the government law, Last but not least, the accounting personnel will be difficult in the rural environment.

\section{The Town Manages the Charge to an Account Instead of the Village and Its Advantages, Disadvantages.}

This mode must clear the property relations of the village, After decided by all the villagers' congress, the villagers will sign an agreement with the government. On the one hand, the financial agent system is a management system that can give play to the township (town) talent advantage 、 business advantages、 the village-level financial unified financial system、 unified billing 、 unified examination、 unified open and so on. It is helpful to avoid the happening of unlawful phenomenon such as all kinds of illegal misappropriation of funds, to strengthen the village and township level for the work of financial management and supervision, to urge the institutionalization and standardization of rural financial work, greatly improving the quality of accounting information. on the other hand, to a certain extent, the intervention should be in accordance with the law belongs to the scope of the villager autonomy, it is contrary to the principle of villagers' autonomy, This mode can urge the rural corruption, at the same time, it also can cause other problems, Once there is an mistake, nobody will take the mistake, this will influence the work enthusiasm.

\section{Accounting Examination Agency Financial Management Mode and Its Advantages and Disadvantages}

After villager congress votes, an agency agreement will be signed with the professional accounting services, it will provide the financial work for accounting and management. This mode is to handle the agency relationship with villagers' autonomy and the relationship between flexibility and unity properly.

The market management is introduced into this mode, the agency is a relatively independent third party, according to the contract for making money, it has no other interests with the village committee, it changes the original subsidiary position of accounting personnel, it avoids the village cadres have a corruption, at the same time, the agency system can guarantee the standardization of the accounting work, but the agency needs some agent fee, it increases the villagers' burden in some areas.

\section{The Cause of Four Kinds of Management Mode of Failure}

\section{The Quality of the Rural Grassroots Accounting Personnel is very Weak, the Cultural Level is Generally Low.}

Most of the rural grassroots accounting personnel have not a formal accounting training, the vast majority of people did not even the most basic accountant from job seniority card, having never learned the basic accounting principles and procedures, and in many areas the position is occupied by the village cadres. This is mainly due to our country rural basic present situation, most rural have an exclusive thought, this is not conducive to external professional with higher levels when they want to work smoothly, and village cadres occupy village accounting position, it will provide the convenience for its corruption, leading to democratic financial management of village-level financial disclosure system is not effective implementation.

In addition, the traditional cultural thoughts on the impact of the broad masses at the grass-roots level is deep, the history of several thousand years has shown that the broad masses of rural grassroots group is the world's most industrious, but at the same time, thousands of years of Confucianism also profoundly affects our country rural grassroots masses, subconscious dominate 
their behavior, they advocate" reconciliation ", they have a very strong endurance, it is contrary with the purpose of the rural grass-roots mass self-government unbecoming. Therefore, the rural grass-roots needs to improve its ownership responsibility consciousness, give play to the role of its oversight role, this is another aspect of improving accounting environment.

\section{The Accounts Have a Confusion, the Illegal Phenomenon in Some Areas is Still Widespread.}

For a long time, the confusion of the rural grass-roots financial management has a close relationship with foreign-funded corruption, embezzlement, occupy, it is also closely related to the abuse of power and village cadres.

The legal system of Some cadres viewpoint is weak due to lower cultural quality, in some matters involving the interests of the village collective, they only listen to themselves. This mainly displays in: firstly, abuse power for personal gains, secondly, "open off-balance-sheet accounts", "note for library" wait for a phenomenon is more serious, thirdly, the accounting subject setting is awful, it isn't in line with financial regulations.

The Rural Grass-roots Financial System is Not Sound, the Breadth and Depth of the Accounting Management System Reform is not Enough.

In many areas, the rural grass-roots financial system is not perfect, mainly displays in: firstly, final accounts did not establish financial budget system, Secondly, the monetary fund management system is weak, leading to some village cadres use collective funds illegally, Thirdly, the collective asset management system is not transparent, some village cadres in involving the interests of the village collective is greedy.

\section{The Rural Grass-roots Level of the Accounting Computerization is Not Deep, the Accounting Information Construction is Weak.}

In the place of the implementation of the existing conditions of rural accounting computerization is the trend of modernization and standardization of accounting to rural grassroots, but because of China's rural financial information starts late, China's rural financial information platform is still imperfect. It mainly displays in: the balance of eastern and western economic development lead to regional difference of hardware facilities, especially in some parts of the Midwest, it is still the one of network information "isolated island". Secondly, the level of professional and technical limitations in the rural grass-roots financial personnel lead to backward, thirdly, lack of rural grassroots special financial software, the existing financial software is used by the enterprise, the system operation is not flexible, in some areas it cannot adapt to the needs of the rural grassroots financial work, and the choice of accounting software is multifarious, around the lack of a unified and efficient software.

\section{The Solutions about the Above Questions}

Developing the Talent Planning, Enhancing the Professional Quality Level of the Accounting Personnel, Improving Accounting Cultural Environment at the Local Level.

As the quality of the accountants is very low in the rural area in China, we must develop a plan, cultivate a high-quality accounting team, the training should be conducted on a regular basis accounting personnel at the grass-roots level, Making the poor ability of rural grassroots accounting team have an ending.

If we want to improve the human environment in basic accounting, we need to mobilize the responsibility consciousness of the villagers masters, we must give play to the role of the villagers' 
democratic supervision, accounting personnel at the grass-roots level should listen to the advice of the masses, answer the question of the masses, involving the interests of the village collective should have a financial disclosure, accept the supervision of the villagers.

\section{Improve the Independence of the Accounting Personnel, Improve the System of Village Cadres' Departure Audit.}

For the accounting personnel at the grass-roots level, we should choose reasonable decent and professional personnel, it has not a relationship with the village cadres, building a village financial management team to participate in the audit, they audit the financial accounts of collective economic organizations and related economic activities.

\section{Improve the Financial System at the Primary Level, Promote the Reform of Accounting Management System, Change the Basic System Environment}

The accounting management system in rural grassroots is not limited to the above four patterns, on the basis of standardization, each region should combine with the actual, adjust measures to local conditions, to explore other accounting management systems. For the reform of accounting management system, it can change from the following several aspects: one, each region should explore build system about financial revenue and expenditure budget, Two, improving the system of check reimbursement, the cash income generally charged by village reimbursement, anyone may intercept cash, Three, improving cost quota system, controlling the entertainment expenses, controlling the non-productive expenditure, Four, we will improve the system of collective asset management, operational assets must be uniform, the contract should date back to the town of village-level financial management center, it is forbidden to sign the oral contract. The assets changing must be registered in time. Every year we should have a full inventory of collective assets, preventing the loss of collective assets.

\section{Continuing to Promote the Rural Information Construction, Improving the Hardware Facilities of the Accounting}

Construction the rural financial information have a great significance, of course, this must be suitable for the country, it is beneficial to promote the standardization of the rural financial work, promote the transformation of rural modernization management thought, also help the government grasp the operation of the rural collective economy, strengthen the supervision and guide the rural financial work timely and accurately.

In particular, we should solve it from the following several aspects: firstly, planning and constructing the information hardware facilities, using a unified rural financial software that should be developed, software development should be fully aware of the rural financial information and the needs of the broad masses at the grass-roots level, Secondly, attaching great importance to the training of financial information for accounting personnel knowledge, making them have a scientific management skills ,Thirdly, strengthening the supervision of the network, the rural financial information construction provides a new conditions to strengthen the supervision of network.

\section{Summary}

In this paper, based on the analysis of the rural grassroots accounting management mode, points out that some questions in the rural financial work, accounting personnel quality is low, grass-roots financial system is not sound, accounting management system reform is not enough, accounting 
information level is low and so on ,put forward to improve the human environment, institutional environment, hardware infrastructure environment and a series of measures, hope to have a help to the rural grassroots financial work standardization, information and modernization.

\section{References}

[1] Zhi-Lin Liu . The factor analysis and strategy innovation that impacts the rural financial information [J]. Journal of business research (2007): 89-96.

[2] Hai-Yan Liu. Speeding up the new exploration about the process of rural financial information, [J].The accounting of China's township enterprises (2013): 45-58.

[3] Tie-Yu Liang. The problems and countermeasures about the rural accounting [J]. Journal of SCIENTIFIC RESEARCH: (2011): 35-38.

[4] Yi-Man Xu. The current rural financial management model [J]. Journal of accounting research (2013): 27-29.

[5] Wei-Xing Qin. The study of rural accounting standardization construction [J]. Journal of accounting research (2012): 13-24

[6] Ingram, Robert W, Economic incentives and the choice of state government accounting practices, [J]. Journal of Accounting Research (1984): 126-144. 